Vol.45, n. 4 : pp. 531-535, December 2002

ISSN 1516-8913 Printed in Brazil

AN INTERNATIONAL JOURNAL

\title{
Chemical Composition of Pleurotus pulmonarius (Fr.) Quél., Substrates and Residue after Cultivation
}

\author{
Sueli Oliveira Silva ${ }^{1}$, Sandra Maria Gomes da Costa ${ }^{2}$ and Edmar Clemente ${ }^{1 *}$ \\ ${ }^{I}$ Departamento de Química; Universidade Estadual de Maringá; Av. Colombo, 5790; 87020-900; Maringá - PR - Brazil. \\ ${ }^{2}$ Departamento de Biologia; Universidade Estadual de Maringá; Av. Colombo, 5790; 87020-900; Maringá - PR - Brazil
}

\begin{abstract}
The cultivation of Pleurotus pulmonarius was carried out on different substrate: cotton waste (A) leaves of Cymbopogon citratus (B) and leaves of Panicum maximum Jacq. (C). The mushroom had a varied chemical composition; nevertheless they contained a good composition for to be used as a good source of protein for human kind. The results showed the higher protein content (29.19\%) and fibre (9.0\%) for the mushroom that were cultivated on cotton peel. The substrate composition and the residue composition after the mushroom harvest were: Protein for the substrate " $A$ " (10.63\% and 9.35\%), "B" (7.87\% and 4.24\%) and "C" (7.55\% and $5.90 \%)$; Lipids " $A$ " (4.17\% and 2.03\%), "B"(2.77\% and 3.20\%) and " $C$ " (0.91\% and 2.05\%); Fibres " $A$ " (49.02\% and 37.02\%), $" B "(28.40 \%$ and $23.26 \%)$ and " $C "$ " (37.50\% and $26.66 \%)$ respectively. The substrate " $A$ " showed $0.048 \%$ of iron and " $C$ " $0.14 \%$ of magnesium, $0.31 \%$ of potassium and $0.26 \%$ of calcium. In the substrate " $B$ " the quantity of the minerals were very low in comparison to the other substrates. The residues after the harvest of mushroom could be used as fertiliser or as complement in the composition for animal feed.
\end{abstract}

Key words: Edible mushroom, chemical composition, Panicum maximum Jacq., Cymbopogon citratus, cotton waste

\section{INTRODUCTION}

The cultivation of mushroom constitutes important practice in the modern society due to the fact that this biotechnological process produces food of high nutritious value from agro-industrial substrate, facilitating the reduction of their volume or accelerating its decomposition process. Beside this, it allows the transformed substrate to be used as a fertiliser improving the physical characteristics of the soil or as feed for animal, closing the cycle of use of the raw material (Bononi and Trufem, 1985; Fox, 1993; Maziero and Zadrazil, 1994; Bononi et al., 1995).
Pleurotus species (giant mushroom) is a mushroom constituting excellent dietary food (Crisan and Sands, 1978; El Sayed et al., 1994). Other positive effect of the ingestion of the basidiomas of Pleurotus refers to the lipid metabolism, where it helps in decreasing the free triglycerides preventing the arterioscleroses (Ginter and Bobeck, 1987; Chang and Miles, 1989; Jong and Donovick, 1989, Jong and Birgmingham, 1993; Trinci, 1992). In nature this mushroom specie is an active decomposition of wood and several other substrates. Due to its capacity of secreting spectrum of enzymes, it has ability to colonise and to digest several types of

\footnotetext{
* Author for correspondence
} 
materials containing lignin, cellulose, starch, sugars, and fermented proteins (Bononi and Trufem, 1985; Zadrazil, 1985, 1993;).

Pleurotus species is a mushroom of pleasant flavour and it possesses several proteins, minerals ( $\mathrm{Ca}, \mathrm{P}, \mathrm{Fe}, \mathrm{Mg}$ ), and low carbohydrate quantities and fat, constituting excellent dietary food (Crisan and Sands, 1978; Rollan, 1991; Bononi et al; 1995; Ferreira, 1998).

Those are several substrates that have potential to be good as substrates for the cultivation of this mushroom (Maziero, 1990). The production of edible mushrooms represents a possibility of internal and external market, not yet very explored in Brazil, and could still have several purposes such as food source, elimination and use of substrates, recycle of nutrients, optimisation of the losses of energy, using the residues of the cultivation in the animal feeding, between others.

The literature presents data of the chemical composition of the substrates ("in nature") and of the mushrooms, however nothing was found about the chemical composition of the residue used to cultivate, just texts mentioning the possibility of the use of these residues in the animal feeding. The objective of this work was the chemical composition of the substrates ("in nature") and of the mushrooms cultivated in this different substrate and of the residues after the cultivation.

\section{MATERIAL AND METHODS}

\section{Sample preparation}

Pleurotus was obtained from the Institute of Botany of São Paulo gave the isolated $\left(n^{\circ} 20\right) P$. pulmonarius from its collection of mushroom culture. For matrix production, $5 \mathrm{~mL}$ of inoculum was prepared using middle BD (Fidalgo and Bononi, 1984). The matrix (100g) was carried out using cotton waste. The substrates were pasteurising with water steam at $100^{\circ} \mathrm{C}$ up to 3 hours. Substrates sample of $100 \mathrm{~g}$ were transfered into plastic bags (5L) and inoculated with $100 \mathrm{~g}$ of matrix. After the inoculation, the bags were transfered to greenhouse where the temperature and humidity conditions were $20-25^{\circ} \mathrm{C}$ and 80 $90 \%$ respectively.

Substrates used: Cotton waste (A), leaves of Cymbopogon citratus (B), leaves of Panicum maximum Jacq (C). The samples were triturated using a mill (Marconi, knife crusher) adapted with sieve (diameter of 1 to $5 \mathrm{~mm}$ ) and dried in a stove at $105^{\circ} \mathrm{C}$.

Protein Determination: The determination of protein was carried out following the Micro Kjeldahl method (AOAC, 1984). Considering the conversion factor $\mathrm{N} \times 4.28$ in agreement with (Sturion, 1994 en non-protein $\mathrm{N}$ present in the mushrooms). In the substrates, the factor used was $\mathrm{N} \times 6.25$.

Lipids Determination: The lipids determination was carried out by continuous extraction using Soxhlet apparatus (AOAC, 1984).

Ashes Determination: For ash determination the samples were incinerated at $500^{\circ} \mathrm{C}$, until to have a clear ash (AOAC, 1984).

Glucoses Determination: The assay ware carried out following the methods of Adolfo Lutz Institute (1985).

Fibre Determination: The determination of the fibre content in the samples was done according with the enzymatic gravimetric method (AOAC, 1990).

Determination of $\mathrm{Fe}, \mathrm{K}, \mathrm{Ca}$ and Mg: These assays were carried out using atomic absorption spectrophotometry method; the samples were prepared in acid using ash. The ash was solubilized using $2 \mathrm{~mL}$ de $\mathrm{HCl} 1: 1$ and 2 drops of $\mathrm{HNO}_{3} 12 \mathrm{M}$. After the solubilization, the solution was filtered in to volumetric flask of $50 \mathrm{ml}$ and distilled water was used to fill the flask. Samples were taken from this and a suppresser was added (lanthanium chloride) for calcium and magnesium determination and sodium chloride for potassium determination, AOAC (1984).

\section{RESULTS AND DISCUSSION}

The results of the chemical composition of the substrates are shown in the Table 1. All the assays were carried in triplicate (dry basis). 
Table 1 - Percentage of Protein, Lipids, Ash, Glucoses, Fibre and Minerals in the substrates used for mushroom cultivation $(\mathrm{n}=3)$

\begin{tabular}{lccc}
\hline \multicolumn{1}{c}{ Assays/ Substrate } & $(\mathbf{A})$ & $\mathbf{( B )}$ & $(\mathbf{C})$ \\
\hline Protein (\%) & $10.63 \pm 0.05$ & $7.87 \pm 0.10$ & $7.55 \pm 0.05$ \\
Lipids (\%) & $4.17 \pm 0.13$ & $2.77 \pm 0.07$ & $0.91 \pm 0.02$ \\
Ashes (\%) & $6.85 \pm 0.15$ & $7.40 \pm 0.11$ & $5.97 \pm 0.12$ \\
Glucoses (\%) & $0.80 \pm 0.08$ & $0.67 \pm 0.05$ & $0.79 \pm 0.04$ \\
Fibre (\%) & $49.02 \pm 0.22$ & $28.40 \pm 0.10$ & $37.50 \pm 0.12$ \\
Iron (\%) & $0.048 \pm 0.002$ & $0.039 \pm 0.004$ & $0.006 \pm 0.001$ \\
Magnesium (\%) & $0.0015 \pm 0.0001$ & $0.0012 \pm 0.0001$ & $0.1410 \pm 0.0014$ \\
Potassium (\%) & $0.0085 \pm 0.0002$ & $0.0086 \pm 0.0002$ & $0.3100 \pm 0.0120$ \\
Calcium (\%) & $0.0065 \pm 0.0002$ & $0.0066 \pm 0.0003$ & $0.2600 \pm 0.0150$ \\
\hline
\end{tabular}

$\mathrm{n}=\mathrm{n}^{0}-$ of repetition

Table 2 - Percentage of Protein, Lipids, Ashes, Fibre and Minerals in the fruiting bodies of Pleurotus pulmonarius (Fr.) Quél., cultivated on different substrates. $(n=3)$

\begin{tabular}{cccc}
\hline Assays / Mushroom & $(\mathbf{A})$ & $\mathbf{( B )}$ & $(\mathbf{C})$ \\
\hline Protein (\%) & $20.03 \pm 0.04$ & $16.90 \pm 0.03$ & $26.82 \pm 0.10$ \\
Lipids (\%) & $2.62 \pm 0.43$ & $2.02 \pm 0.20$ & $1.05 \pm 0.10$ \\
Ashes (\%) & $7.33 \pm 0.13$ & $5.86 \pm 0.13$ & $7.07 \pm 0.15$ \\
Fibre (\%) & $9.00 \pm 0.01$ & $4.00 \pm 0.01$ & $4.94 \pm 0.02$ \\
Iron (\%) & $0.0075 \pm 0.0001$ & $0.0154 \pm 0.0012$ & $0.0105 \pm 0.001$ \\
Magnesium (\%) & $0.2593 \pm 0.002$ & $0.1011 \pm 0.001$ & $0.0707 \pm 0.001$ \\
Potassium (\%) & $2.3709 \pm 0.0020$ & $1.9941 \pm 0.0030$ & $0.5790 \pm 0.0020$ \\
Calcium (\%) & $0.0038 \pm 0.0002$ & $0.0684 \pm 0.0011$ & $0.0034 \pm 0.0002$ \\
\hline
\end{tabular}

$\mathrm{n}=\mathrm{n}^{0}$ of repetitions

Evidenthy cotton waste (A) was the one that, presented the largest percentage in most of the accomplished determinations, was richest substrate in protein, lipids, glucides and fibre.

The analysis of the fruiting bodies (Table 2) showed that the mushroom possesse a varied development. Among the substrates used for cultivation the C. citratus showed lowest protein contents.

The values were close to the values mentioned by Maziero (1990) and Sturion and Oetterer (1995) who studied the chemical composition of edible mushroom cultivated on stem and leaves of banana tree and wheat straw.

Among the minerals potassium appeared in larger amount when compared to (iron, magnesium and calcium) folowing comes magnesium and in small amounts iron and calcium. This variation was due to the different mineral composition of the substrates used for the cultivation (Sturion and Oetterer, 1995).

The results demonstrated that the best substrates for cultivation of edible mushroom was cotton waste, where the concentration of magnesium and potassium were larger in the mushroom picked in relation to the substrate $\mathrm{B}$ (C. citratus), in which the concentration of iron and calcium was higher (Strmiskova et al., 1992). The lower amount of minerals was obtained in the substrate $\mathrm{C}(P$. maximum). Also for the other assays, (protein, lipids, fibre and ash) cotton wastes showed as the best substrate. However the highest percentage of protein was found in the mushroom cultivated in $P$. maximum. In a comparative study it can be evaluated that the amount of protein, for example, in the mushroom cultivated in the cotton waste substrate $(20 \%)$ can be considered higher than the protein contained and substrate after and before cultivation. The high protein percentage in the mushroom, shown that it can be a great protein source in the feeding for humans and the efficiency of the cotton waste substrate, and the high protein contend in the residue of it indicate the capacity of the mushroom has to develop and still to contribute for a protein deposit in the residue owed the mycelium. The lipids percentage 
observed in that mushroom were lower, shown which the mushroom are lower caloric food great for a diet that does not allow cholesterol (Crisan and Sands, 1978; Ginter and Bobek, 1987).
The fibre contents indicated that the mushrooms are also efficient as participants in the intestinal regulation.

Table 3 - Percentage of Protein, Lipids, Ashes, Glucoses, Fibre and Minerals in the residue after the mushrooms cultivation. $(\mathrm{n}=3)$

\begin{tabular}{cccc}
\hline Assays / Residue & (A) & (B) & (C) \\
\hline Protein (\%) & $9.35 \pm 0.32$ & $4.24 \pm 0.09$ & $5.90 \pm 0.41$ \\
Lipids (\%) & $2.03 \pm 0.33$ & $3.20 \pm 0.34$ & $2.05 \pm 0.58$ \\
Ashes (\%) & $9.20 \pm 0.15$ & $9.55 \pm 0.21$ & $7.90 \pm 0.20$ \\
Glucoses (\%) & $0.90 \pm 0.15$ & $1.35 \pm 0.07$ & $0.90 \pm 0.90$ \\
Fibre (\%) & $37.06 \pm 0.90$ & $23.26 \pm 2.04$ & $26.66 \pm 2.25$ \\
Iron (\%) & $0.0807 \pm 0.0026$ & $0.0671 \pm 0.0022$ & $0.0186 \pm 0.0001$ \\
Magnesium (\%) & $0.1039 \pm 0.0006$ & $0.0890 \pm 0.0034$ & $0.2496 \pm 0.0072$ \\
Potassium (\%) & $0.4324 \pm 0.0002$ & $0.4535 \pm 0.0044$ & $1.8214 \pm 0.0351$ \\
Calcium (\%) & $2.7350 \pm 0.2121$ & $1.5712 \pm 0.4790$ & $0.7398 \pm 0.0435$ \\
\hline
\end{tabular}

$\mathrm{n}=\mathrm{n}^{\underline{0}}$ of repetition

The results obtained residues demonstrated that the cotton residue had best protein concentrations of the fibre, iron and calcium. C. citratus presented larger ash concentrations and $P$. maximum presented larger concentration of magnesium (Table 3). It was observed that after the development of the mushroom these substrates presented modifications in its chemical composition. For example, lower fibre contents due to lignin and cellulose degradation by the mushroom. This degradation would increase the digestibility of this residue and also has a considerable protein content, due to the presence of mycelium. Therefore, this residue after the cultivation can be used as nutritional complement in rations for animals feeding.

The results demonstrated it is possible to use of the residue, which was cultivating the edible mushroom for compose rations or could be used as feeding complement for animals.

\section{CONCLUSION}

- Among the used substrates of cotton waste produced mushroom with maximum protein contents.

- The substrates used for the cultivation influenced the chemical composition of the mushroom.
- The residue after the cultivation had its digestibility increased which gave the possibility for use as animal feed.

- The North of Paraná is a high producer of cotton; therefore the possibility to get larger amounts of cotton waste, which could be one way to increase the mushroom cultivation in the region.

\section{ACKNOWLEDGEMENT}

We thank to CNPq for the scholarship of IC.

\section{RESUMO}

O cultivo de Pleurotus pulmonarius foi realizado em diferentes substratos: resíduo da cultura de algodão (A), folhas do capim Cymbopogon citratus (B), folhas do capim Panicum maximum Jacq. (C). Os cogumelos cultivados usando estes substratos apresentaram uma composição química variada, mas no entanto eles continuam tendo condições de serem usados com fonte de proteína pelos seres humanos. Os resultados mostraram um alto teor de proteína $(29,19 \%)$ e $(9,0 \%)$ de fibras para os cogumelos cultivados em resíduo de algodão. As composições dos substratos e dos resíduos após o cultivo foram: Proteína para o substrato A $(10,63 \%$ e $9,35 \%)$, B $(7,87 \%$ e $4,24 \%)$ e C $(7,55 \%$ e $5,90 \%)$; Lipídios A $(4,17 \%$ e 
$2,03 \%)$, B $(2,77 \%$ e $3,20 \%)$ e C $(0,91 \%$ e $2,05 \%)$; Fibras A $(49,02 \%$ e $37,02 \%)$, B $(28,40 \%$ e $23,26 \%)$ e C $(37,50 \%$ e $26.66 \%)$ respectivamente. Entre os minerais analisados, no substrato A os resultados mostraram $0,048 \%$ de ferro e no substrato C $0.14 \%$ de Magnésio, $0,31 \%$ de Potássio e $0,26 \%$ de Cálcio, no substrato B somente pequenas quantidades foram detectadas quando comparado os outros substratos. Estes resíduos de cultivo de cogumelos comestíveis podem ainda ser utilizados como adubo ou como alimento para animais.

\section{REFERENCES}

Association of Official Analytical Chemistry - AOAC. (1984), Official methods of analysis of the Association of Official Analytical Chemists. 14. ed. Arlington. $1141 \mathrm{pp}$.

Association of Official Analytical Chemistry - AOAC. (1990), Official methods of analysis of the Association of Official Analytical Chemists. 15. ed. Arlington. 1105-1106 pp.

Bononi, V. L. R.; Capelari, M.; Maziero, R. and Trufem, S. F. B.(1995), Cultivo de Cogumelos Comestiveis. São Paulo : Icone Editora LTDA. (Brasil Agrícola). 206 pp.

Bononi, V. L. R. and Turfem, S. F. B. (1985), Cogumelos comestíveis. São Paulo : Ícone Editora LTDA. 83 pp.

Chang, S. T. and Miles, P. G. (1992), Mushroom Biology a new discipline. Mycologist., 6 : (2), 64-65.

Crisan, E. V. and Sands, A. (1978), Nutritional value. In: Chang, S. T. and Hayes, W. A. (eds.). The Biology and Cultivation of Edible Mushrooms. New York : Academic Press. pp.251-293.

Ferreira, J. E. F. (1998), Produção de Cogumelos. Guaíba, RS : Livraria e Editora Agropecuária Ltda. 137 pp.

Fidalgo, O. and Bononi, V. L. R. (1984), Manual prático de coleta, herborização e preservação. São Paulo : Instituto de Botânica do Estado de São Paulo. 40 pp.

Fox, F. M. (1993), Tropical fungi: their commercial potencial. In: Isaac, S; Frankland, J. C.; Watling, R. and Whalley, A. J. S. (eds.). Aspects of Tropical Mycology. Cambridge : Cambridge University Press. 325 pp.

Ginter, E. and Bobek, P. (1987), The perspective of Pleurotus in human nutrition. Proc. of the II Meeting of Pleurotus growers, Bratislava.

Instituto Adolfo Lutz. (1985), Normas Analiticas: Métodos Químicos e Físicos para Análise de Alimentos, 3. ed. São Paulo. 533 pp.
Jong, S. C. and Birgmingham, J. M. (1993), Medicinal and therapeutic value of the shiitake mushroom. Advances in Applied Microbiology, 39, 153-184.

Jong, S. C. and Donovick, R. (1989), Antitumor and antiviral substances of fungi. Advances in Applied Microbiology, 34, 183-262.

Maziero, R. (1990), Substratos alternativos para o cultivo de Pleurotus spp. MSc Thesis, Instituto de Biociências - USP. São Paulo. 136 pp.

Maziero, R. and Zadrazil, F. (1994), Effects of different heat pre-treatments of wheat straw on its microbial activity and colonization by different tropical an subtropical edible mushrooms. World Journal of Microbiology and Biotechnology, 10, 74-380.

Rajarathnam, S.; Shashireka, M. N. and Bano, Z. (1992), Biopotentialities of the Basidiomacromycetes. Advances in Applied Microbiology, 37, 233-361.

Rolan, M. G. (1991), Cultivo de setas e trufas. 2. ed. Madrid : Ediciones Mundi-Prensa. 174 pp.

Strmiskova, G.; Strmiska, F. and Dubravicky, J. (1992), Mineral composition of oyster mushrooms. Nahrung. Bratislova, 36 : (2),210-12.

Sturion, G. L. (1994), Utilização da folha de bananeira como substrato para o cultivo de cogumelos comestiveis (Pleurotus spp). MSc Thesis, ESALQ, Piracicaba. $147 \mathrm{pp}$.

Sturion, G. L. and Oetterer, M. (1995), Composição Química de Cogumelos comestíveis Pleurotus spp.) originados de cultivos em diferentes substratos. Ciência e Tecnologia de Alimentos, 15 : (2),189-193.

Trinci, A. P. J. (1992), Myco-protein: a twenty-year overnight sucess story. Mycological Research, 96 : (1), $1-13$.

Zadrazil, F. (1985), Screening of fungi for lignin decomposition and conversion of straw into feed. Angew. Bot., 59, 433-452.

Zadrazil, F. (1993), Conversion of lignocellulosics into animal feed with white-rot fungi. In: Chang, S. T.; Buswell, J. A. and Chiu, S. W. (eds.). Mushroom Biology and Mushroom Products. Hong Kong : The Chinese University Press. 370 pp.

Received: October 16, 2000; Revised: July 13, 2001; Accepted: January 18, 2002. 